\title{
Decision Support System Determining Computer Virus Protection Applications Using Simple Additive Weighting (SAW) Method
}

\author{
Adi Widarma ${ }^{1 *}$, M. Dedi $\operatorname{Irawan}^{2)}$, Fajri Nurhidayahti ${ }^{3)}$, Ranis Hsb ${ }^{4)}$ \\ ${ }^{1)}$ Universitas Asahan, Indonesia, ${ }^{2334)}$ Universitas Islam Negeri Sumatera Utara, Indonesia \\ ${ }^{1)}$ adiwidarma10@gmail.com, ${ }^{2}$ muhammaddediirawan@uinsu.ac.id, ${ }^{3)}$ fajrinurhidayahti08@gmail.com, \\ ${ }^{4)}$ ranishasibuan11@gmail.com
}

\begin{abstract}
The use of information technology devices such as computers or laptops is currently increasing. The increased use is due to the fact that these devices are very supportive of our daily work activities. With the increasing use of these computers, data security on a computer or laptop device must be completely safe from virus attacks. To ward off viral attacks $m$ aka requires the application of anti-virus to inhibit and prevent a variety of viruses that enter into the computer system so that the computer user's activity was not bothered by the many viruses are easily spread. Because there are too many antiviruses on the market, it is necessary to choose a good antivirus. One of the ways to choose antivirus is the existence of a decision support system. In this study, the Simple Additive Weighting (SAW) method was applied for the anti-virus application selection system. This data assessment analysis aims to produce the best anti - virus application options that computer users can use to secure their computer data. The criteria and weights used are $\mathrm{K} 1=$ application rating $(5 \%), \mathrm{K} 2=$ completeness of features $(30 \%), \mathrm{K} 3=$ price $/$ official license $(5 \%), \mathrm{K} 4$ $=$ malware detection $(45 \%)$ and $\mathrm{K} 5$ = blocking URL (15\%). Of the 25 alternatives used, the results of the study, namely alternative $\mathrm{A} 1=$ Kaspersky anti-virus get the highest ranking result.
\end{abstract}

Keywords: Computer; Virus; Protection; Simple Additive Weighting (SAW); System

\section{INTRODUCTION}

Along with the development of information technology, the need for information technology devices is deemed very important. The use of information technology devices such as computers or laptops is currently increasing. The increased use is due to the fact that these devices are very supportive of our daily work activities. With the increasing use of these computers, data security on a computer or laptop device must be completely safe. Data and information traffic that is often used will pose a threat in itself. Threats that often arise come from a program designed to destroy data, namely viruses (Primandari, 2016). A computer virus is a small program written to change the way a computer operates, without the user's permission or knowledge so that later the virus will change the size of the infected program (Hermawan, 2016). Viruses must meet two criteria: self-run and often place their own code in the execution path of other programs and replicate themselves.

To protect and ward off data from damage caused by the virus, a computer protection application is needed, namely anti-virus protection software with the aim of inhibiting and preventing various viruses from entering the computer system so that the activity of computer users is not disturbed by the many viruses that easily spread. . Spybot is an example of an anti-spyware tool that identifies and removes types of malware very well, so we must always update it (Hermawan, 2016).

Anti-virus software is an entry level version of virus protection for our PC. All antivirus software to block or remove spyware, worms, root kits, and other types of malware. On the other hand, this particular virus protection software has fewer features than the two anti - virus suites. This software is including abilities to scan incoming emails for looking for potential threats, automatically clean or quarantine infected files, and create a rescue disk which can be in the boot, to mention a few of the many features.

The use of virus protection software must need attention, where the selection in using antivirus must be right so that the results obtained will be maximized. In determining the right virus protection option, a decision support system can be used. In this study, the Simple Additive Weighting (SAW) method was used in determining the selection of virus protection used on computer devices. Simple Additive Weighting method is one part of the Multiple Criteria Decision Analysis (MCDA) which can be applied to solve various decision-making problems in real life(Kaliszewski

* Corresponding author

This is an Creative Commons License This work is licensed under a Creative

Commons Attribution-NoDerivatives 4.0 International License. 


\section{Journal of Computer Networks, Architecture and High Performance Computing}

Volume 3, Number 1, Januari 2021

https://doi.org/10.47709/cnapc.v3i1.936
Submitted : 12 February 2021

Accepted : 23 February 2021

Published : 2 March 2021

\& Podkopaev, 2016).The selection method using Simple Additive Weighting (SAW) can choose the best from several alternatives using each criterion(Haswan, 2019). Sources of data obtained regarding the application were obtained from comparative assessments on anti-virus application websites and other sources. So that problems on the part of computer users can't feel safe to use the application.

\section{Previous Research}

\section{LITERATURE REVIEW}

Research of anti - virus ever done in the selection anti - virus using the Analytic Hierarchy Process (AHP) is generated based on the criteria of the facility is preferably Norton, based on the criteria of preferred quality is a vira and based on the level of popularity of Kaspersky anti - virus like (Primandari, 2016). Research (Saputri, 2018) on the selection of antivirus software for laboratories using the Analytic Hierarchy Process (AHP) method resulted in AVG anti - virus being the right choice because it received the highest priority. Subsequent research with the title Decision making model design for antivirus software selection using Factor Analysis and Analytical Hierarchy Process produced The priority weight score factors are: Performance, Internal, Capacity, Security, Time(Nurhayati, Gautama, \& Naseer, 2018). The results of research (Devi \& Kumar, 2016)on an analysis of the type of anti - virus produced by Kaspersky anti - virus are the best antivirus software because of their good performance in the form of features, support and a satisfying user experience.The research conducted by(Niroomand, Mosallaeipour, \& Mahmoodirad, 2020) producing a new modified version of the Simple Additive Weighting (SAW) method, the novelty includes overcoming the time interval value, keeping the possibility of choosing the best set of locations among all possible locations as well as for the managerial limitations of the problem.

\section{Decision Support System}

Decision support systems are computer-based interactive systems in helping decision makers by utilizing data and models to solve unstructured problems so that the system must be simple, easy to control, complete and adaptable(Limbong \& dkk, 2020). Decision support systems are information generating systems that have to be resolved to assist managers in making decisions in solving certain problems(Nurmalini \& Rahim, 2017). Some examples of the use of decision support systems come from research (Widarma, Siregar, Irawan, \& Fadhillah, 2020)where the decision support system is used to determine the place of KKN (Real Work Lecture) using the fuzzy logic method, then the next example is research(Handika Siregar, Dedi Irawan, \& Hazarin Aulia Chaniago, 2020), namely the application of the Analytic Hierarchy Process (AHP) method in the recruitment of security officers.Basically, a decision support system is designed to support all stages of decision making starting from identifying problems, defining the approach used in decision making, selecting relevant data, and the process of selecting alternatives(Senthil Kumar \& Malathi, 2018).

\section{Simple Additive Weighting (SAW) Method}

The Simple Additive Weighting (SAW) method or often known as the weighted addition method is part of the Multi Criteria Decision Making (MCDM) which calculates the sum of the weights of the performance of each alternative on all the criteria it has. The basic concept of the SAW method is to find the sum of the weighted performance ratings for each alternative on all attributes(Nurmalini \& Rahim, 2017). This method is most widely used which requires the decision maker to determine a weight for each attribute. The rating in each attribute must pass the previous matrix normalization process (Sari, 2018)(Tanjung \& Adawiyah, 2019). To perform normalization, the formula is used:

$$
\mathrm{r}_{\mathrm{ij}}=\left\{\begin{array}{l}
\frac{x_{i j}}{\operatorname{Max}_{i}\left(x_{i j}\right)} \text { if } \mathrm{j} \text { is the profit attribute } \\
\frac{\operatorname{Min}_{i}\left(x_{i j}\right)}{x_{i j}} \text { if } \mathrm{j} \text { is the cost attribute }
\end{array}\right.
$$

where:

$\mathrm{r}_{\mathrm{ij}}=$ normalized performance rating

$\mathrm{Max}_{\mathrm{ij}}=$ maximum value of each row and column 
$\operatorname{Min}_{\mathrm{ij}}=$ minimum value of each row and column

$\mathrm{x}_{\mathrm{ij}}=$ rows and columns of the matrix

The preference value for each alternative uses the formula:

$$
V_{i}=\sum_{j=1}^{n} w_{j} r_{i j}
$$

where:

$\mathrm{V}_{\mathrm{i}}=$ The final value of the alternatives

$\mathrm{w}_{\mathrm{j}}=$ Weight has been determined

$r_{i j}=$ Normalized matrix, a larger value $V_{i}$ indicates that alternative $A_{i}$ is preferred

\section{METHOD}

Step - step decision support system using methods Simple Additive Weighting (SAW) is:

1. Defining several criteria (attribute, weight, rating) that will be used as a reference in making decisions.

2. Determine the variable value of each criterion .

3. Determine alternative of destination decision to be taken.

4. Create a decision matrix.

5. Normalize the matrix based on the formula according to its attributes (cost or profit).

6. Do the sum of the normalized matrix multiplication with the weight of the criteria in order to obtain the best alternative solution based on the largest rank.

From the steps of the decision support system using the Simple Additive Weighting (SAW) method above, in general, this research model can be described in the flowchart figure 1 below.

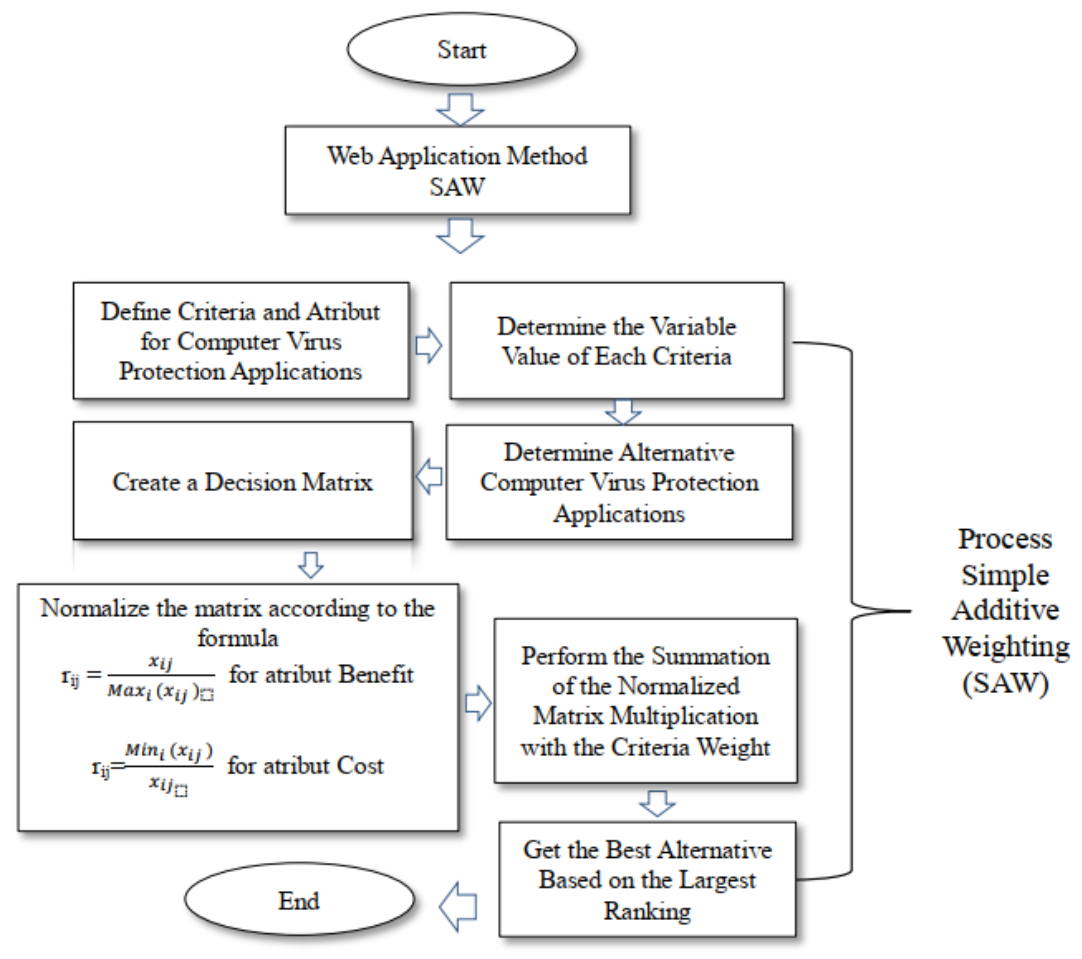

Fig. 1 Research Methods Flowchart 


\section{Determine Assessment Criteria and Attributes}

\section{RESULT}

The assessment criteria were obtained from the assessment of the standardized size of computer virus applications. The criteria and assessment attributes are:

1. Application Rating (Benefit).

2. Completeness of Features (Benefit)

3. Price / Official license (Cost)

4. Malware Detector (Benefit)

5. Malicious Url Blocking (Benefit)

\section{Determine the Weight of Each Criterion}

Researchers have determined the weight of the criteria vector and supporting reasons, in order to serve as a benchmark in the final process ranking. System decision makers will choose a computer virus application as a solution to most users' computers to secure your account and data are held. There are various reasons that are used to assess the weight of the predetermined criteria, namely:

\section{a) Application Rating}

It is an aspect of the assessment of the application that is generated from the app user evaluators . This source is obtained from the computer owner who uses the anti-virus application and the weight is $5 \%$.

b) Completeness of Features

Is an aspect assessment of the application of some of the features that flow contained in the anti-virus application.

- Detects Malware (viral applications), advertising software, virusescomputers and others .

- The ability to detect local viruses.

- Application auto-update capability

- Having p potential protective firewall (activation of external computer access)

- Clean ability (delete unnecessary files)

- Fitur block url (website address is forbidden)

- USB protaction capability

- Password manager

- Parental control setting capabilities

- File backup and restore capabilities

- Webcam protection

- Use of a VPN

So the more complete the features produced by the application, the better the quality of the anti-virus application and the weight is $30 \%$.

c) Price / Official License

Official license price there are free and paid. For ordinary users, of course, the more free the application is, the more it uses the application and its weight is $5 \%$.

d) Malware Detector

It is the application's ability to detect malware viruses, the more they are detected, the application is classified as good and its weight is $45 \%$ (sea.pcmag.com).

e) Malicious URL Blocking

It is the application's ability to block or intercept the url that is harmful to your computer automatically whose weight is $15 \%$.

For more details, the weight of each criteria is shown in Table 1 below. 
Table 1

Criteria, Attributes and Weight of Assessment

\begin{tabular}{cclcc}
\hline No & Criteria Code & \multicolumn{1}{c}{ Criteria } & Atribut & Weight \\
\hline 1 & K1 & Application Rate & Benefit & $5 \%$ \\
2 & K2 & Completeness of features & Benefit & $30 \%$ \\
3 & K3 & Price / official license & Cost & $5 \%$ \\
4 & K4 & Malware detector & Benefit & $45 \%$ \\
5 & K5 & Malicious URL Blocking & Benefit & $15 \%$ \\
\hline
\end{tabular}

Determine the Variables and Variable Weight Value for Each Criteria is shown in Table 2 below.

Table 2.

Variables and Variable Weight Value for Each Criteria

\begin{tabular}{cccccccccc}
\hline $\begin{array}{c}\text { Criteria } \\
(\text { K1 })\end{array}$ & Weight & $\begin{array}{c}\text { Criteria } \\
(\text { K2) }\end{array}$ & Weight & $\begin{array}{c}\text { Criteria } \\
(\text { K3) }\end{array}$ & Weight & $\begin{array}{c}\text { Criteria } \\
(\text { K4) }\end{array}$ & Weight & $\begin{array}{c}\text { Criteria } \\
(\text { K5) }\end{array}$ & Weight \\
\hline 1.0 & 1 & $<2$ & 1 & 0 (free) & 1 & $<70 \%$ & 1 & $<70 \%$ & 1 \\
2.0 & 2 & 3 & 2 & $>0$ (paid) & 2 & $70 \%$ & 2 & $70 \%$ & 2 \\
3.0 & 3 & 4 & 3 & & & $80 \%$ & 3 & $80 \%$ & 3 \\
4.0 & 4 & 5 & 4 & & & $90 \%$ & 4 & $90 \%$ & 4 \\
5.0 & 5 & $>5$ & 5 & & & $100 \%$ & 5 & $100 \%$ & 5 \\
\hline
\end{tabular}

For K2 = Completeness of Features, in table 3 will explain how each alternative compare to the criteria for completing the features that exist in the application. Where the details of some of the application features are as follows:

Table 3

Features Application ComputerVirus

\begin{tabular}{cl}
\hline No. & \multicolumn{1}{c}{ Computer Virus Application Features } \\
\hline 1 & Detects malware (virus applications), advertising software, computer viruses and more \\
2 & Application auto-update capability \\
3 & Has Firewall protection (activation from outside access to the computer) \\
4 & Clean ability (delete unnecessary files) \\
5 & URL block feature (site address prohibited) \\
6 & USB protection capability \\
7 & Password manager \\
8 & Parental control setting capabilities \\
9 & File backup and restore capabilities \\
10 & Webcam protectio \\
11 & VPN protection \\
\hline
\end{tabular}

\section{Determining Alternatives}

The alternatives used in this journal research are as many as 25 alternatives that have different application names and adequate facilities. An alternative is a computer virus protection application as in table 4 below :

Table 4

Alternative Virus Protection Applications

\begin{tabular}{ccl}
\hline No. & Alternatif & \multicolumn{1}{c}{ Information } \\
\hline 1 & A1 & Kaspersky Antivirus \\
2 & A2 & MacAfee Total Protection \\
3 & A3 & Vipre Anti-Virus \\
4 & A4 & Bitdefender Antivirus
\end{tabular}




\begin{tabular}{ccl}
\hline No. & Alternatif & \multicolumn{1}{c}{ Information } \\
\hline 5 & A5 & Avast Anti-Virus \\
6 & A6 & 360 Total Security \\
7 & A7 & Adaware Antivirus 12 \\
8 & A8 & Antivirus - Webroot \\
9 & A9 & Antivirus Comodo \\
10 & A10 & AVG ultimate \\
11 & A11 & Avira Anti-Virus \\
12 & A12 & BullGuard Antivirus \\
13 & A13 & Eset Smart Security \\
14 & A14 & F-Secure Antivirus Aman-Secure \\
15 & A15 & Glarisoft Malware \\
16 & A16 & Heimdal Antivirus \\
17 & A17 & Malwarebytes premium \\
18 & A18 & Microsoft Windows Defender \\
19 & A19 & Norton Security Deluxe \\
20 & A20 & Panda Antivirus \\
21 & A21 & Sophost Home Antivirus \\
22 & A22 & Total Av Antivirus \\
23 & A23 & Trend Micro keamanan maksimal \\
24 & A24 & Windows Security \\
25 & A25 & Zone Alarm Free antivirus \\
\hline
\end{tabular}

Alternative data sources for anti-virus applications are obtained from comparative assessments on anti-virus application websites and other sources. Alternative virus protection data are shown in the following table 5.

Table 5

Alternative Data for Anti-Virus Applications

\begin{tabular}{|c|c|c|c|c|c|c|c|}
\hline No & Alternative & Information & $\begin{array}{c}\text { K1 } \\
\text { (Application } \\
\text { Rate) }\end{array}$ & $\begin{array}{c}\mathrm{K} 2 \\
\text { (Completeness } \\
\text { of features) }\end{array}$ & $\begin{array}{c}\text { K3 } \\
\text { (Price / } \\
\text { official } \\
\text { license) }\end{array}$ & $\begin{array}{c}\text { K4 } \\
\text { (Malware } \\
\text { detector) }\end{array}$ & $\begin{array}{c}\text { K5 } \\
\text { (Malicious } \\
\text { URL } \\
\text { Blocking) }\end{array}$ \\
\hline 1 & A1 & $\begin{array}{l}\text { Kaspersky Antivirus } \\
\text { Mcafee Total }\end{array}$ & 4.5 & 10 & Gratis & $93 \%$ & $91 \%$ \\
\hline 2 & A2 & Protection & 4.0 & 5 & 493272 & $96 \%$ & $100 \%$ \\
\hline 3 & A3 & Vipre Antivirus & 3.0 & 6 & 423680 & $93 \%$ & $100 \%$ \\
\hline 4 & A4 & Bitdefender Antivirus & 4.5 & 5 & 424402 & $78 \%$ & $99 \%$ \\
\hline 5 & A5 & Avast Antivirus & 4.0 & 4 & Gratis & $96 \%$ & $90 \%$ \\
\hline 6 & A6 & 360 Total Security & 2.5 & 3 & Gratis & $60 \%$ & $87 \%$ \\
\hline 7 & A7 & Adaware Antivirus 12 & 2.5 & 5 & Gratis & $83 \%$ & $79 \%$ \\
\hline 8 & A8 & Antivirus-Webroot & 4.5 & 5 & 417000 & $100 \%$ & $80 \%$ \\
\hline 9 & A9 & Antivirus Comodo & 2.5 & 4 & 199000 & $93 \%$ & $56 \%$ \\
\hline 10 & A10 & AVG Ultimate & 4.0 & 4 & Gratis & $89 \%$ & $91 \%$ \\
\hline 11 & A11 & Avira antivirus & 4.5 & 6 & Gratis & $89 \%$ & $81 \%$ \\
\hline 12 & A12 & BullGuard Antivirus & 2.0 & 7 & 337300 & $90 \%$ & $93 \%$ \\
\hline 13 & A13 & $\begin{array}{l}\text { Eset Smart Security } \\
\text { F-Secure Antivirus }\end{array}$ & 3.5 & 5 & 551341 & $93 \%$ & $93 \%$ \\
\hline 14 & A14 & Aman-Secure & 3.5 & 4 & 505810 & $93 \%$ & $99 \%$ \\
\hline 15 & A15 & Glarisoft Malware & 3.5 & 2 & 348049 & $60 \%$ & $89 \%$ \\
\hline
\end{tabular}


Journal of Computer Networks, Architecture and High Performance Computing

Volume 3, Number 1, Januari 2021

https://doi.org/10.47709/cnapc.v3i1.936

Submitted : 12 February 2021

Accepted : 23 February 2021

Published : 2 March 2021

\begin{tabular}{|c|c|c|c|c|c|c|c|}
\hline 16 & A16 & $\begin{array}{l}\text { Heimdal Antivirus } \\
\text { Malwarebytes }\end{array}$ & 4.0 & 3 & 835283 & $98 \%$ & $70 \%$ \\
\hline 17 & A17 & $\begin{array}{l}\text { premium } \\
\text { Microsoft Windows }\end{array}$ & 4.0 & 4 & 730500 & $98 \%$ & $94 \%$ \\
\hline 18 & A18 & $\begin{array}{l}\text { Defender } \\
\text { Norton Security }\end{array}$ & 3.5 & 4 & Gratis & $98 \%$ & $97 \%$ \\
\hline 19 & A19 & Deluxe & 5.0 & 11 & 533000 & $96 \%$ & $97 \%$ \\
\hline 20 & A20 & $\begin{array}{l}\text { Panda Antivirus } \\
\text { Sophost Home }\end{array}$ & 2.5 & 5 & 494160 & $90 \%$ & $35 \%$ \\
\hline 21 & A21 & Antivirus & 2.0 & 2 & Gratis & $98 \%$ & $100 \%$ \\
\hline 22 & A22 & $\begin{array}{l}\text { Total Av Antivirus } \\
\text { Trend Micro } \\
\text { Keamanan }\end{array}$ & 4.0 & 6 & 264556 & $89 \%$ & $12 \%$ \\
\hline 23 & $\mathrm{~A} 23$ & Maksimum & 3.5 & 4 & 420700 & $80 \%$ & $94 \%$ \\
\hline 24 & $\mathrm{~A} 24$ & $\begin{array}{l}\text { Windows Security } \\
\text { Zone Alarm Free }\end{array}$ & 3.5 & 3 & Gratis & $75 \%$ & $80 \%$ \\
\hline 25 & $\mathrm{~A} 25$ & Antivirus & 3.0 & 4 & 280230 & $86 \%$ & $86 \%$ \\
\hline
\end{tabular}

Implementation Method Simple Additive Weighting (SAW) Web-Based

At this stage the Simple Additive Weighting (SAW) method to determine the computer virus application will be implemented using a web-based application. The results of this web-based implementation are as follows:

\section{Determination of Topic Title}

In such systems can dit uliskan headings what we discussed on the web system.

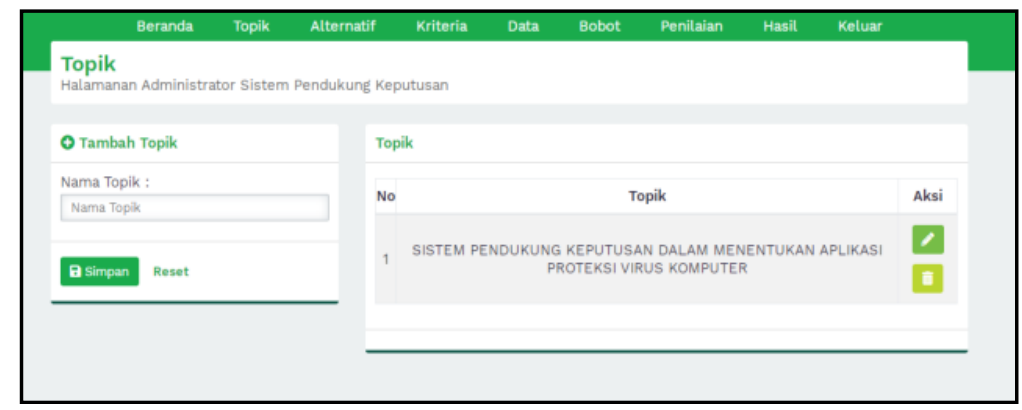

Fig. 2 Add Research topics

\section{Add Assessment Criteria Data}

The next process is to add assessment criteria and attributes.

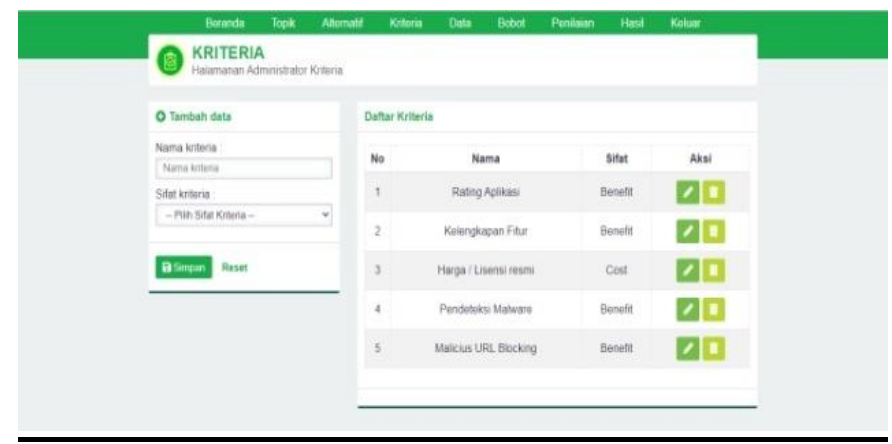

Fig. 3 Add data on assessment criteria and attributes 
Journal of Computer Networks, Architecture and

High Performance Computing

Submitted : 12 February 2021

Volume 3, Number 1, Januari 2021

https://doi.org/10.47709/cnapc.v3i1.936

Accepted : 23 February 2021

Published : 2 March 2021

Adding Weight Data for Each Criterion

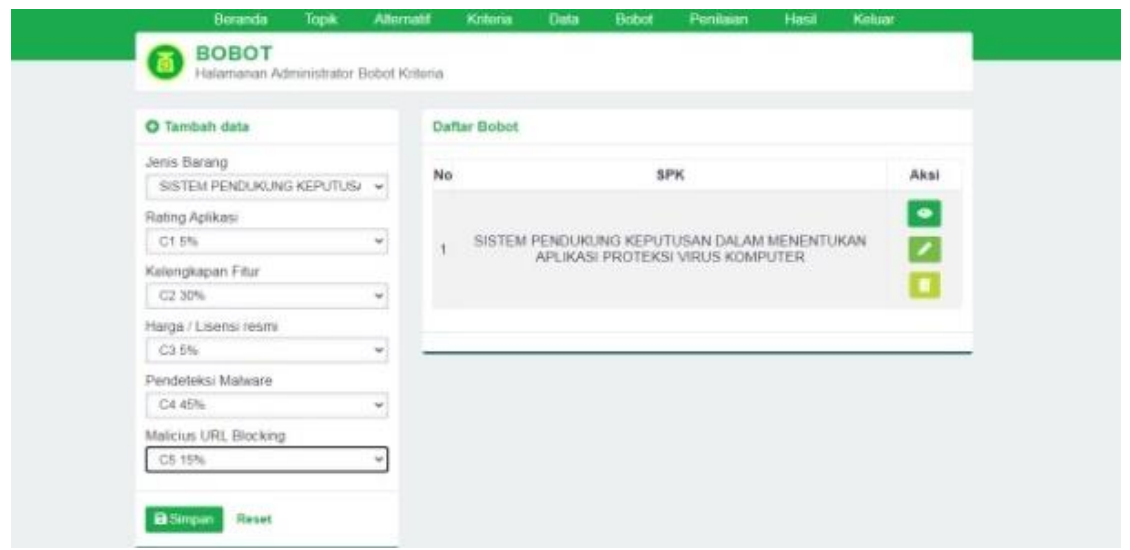

Fig. 4 Weight Data of Each Criterion

In Figure 4 is the weight assessment of each criterion where $\mathrm{K} 1=5 \%, \mathrm{~K} 2=30 \%, \mathrm{~K} 3=5 \%, \mathrm{~K} 4=45 \%$, and $\mathrm{K} 5=$ $15 \%$.

Variable Data and Variable Weights of Each Criterion

In this process, the variable data for each criterion will be added along with the variable weights.

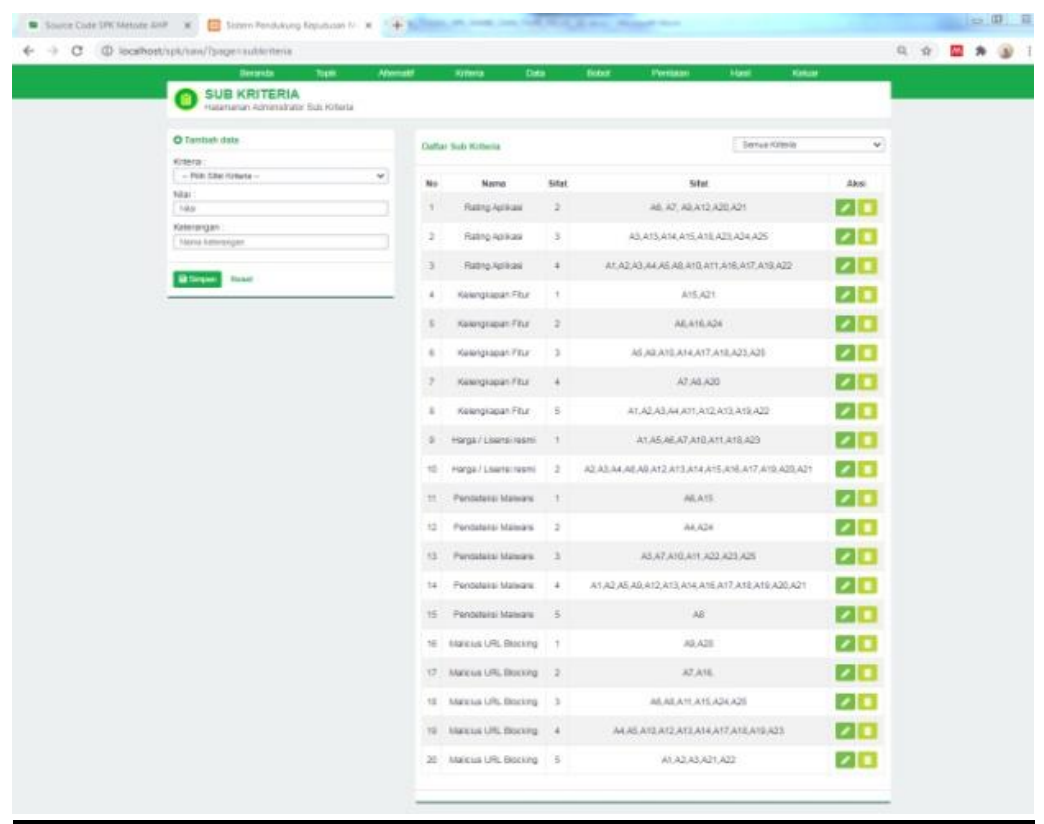

Fig. 5 Adding variables and their weights

Add Alternative Data for Anti-Virus Applications

After entering the topic, then adding data on alternative anti-virus applications 
Journal of Computer Networks, Architecture and

\section{High Performance Computing}

Submitted : 12 February 2021

Volume 3, Number 1, Januari 2021

Accepted : 23 February 2021

https://doi.org/10.47709/cnapc.v3i1.936

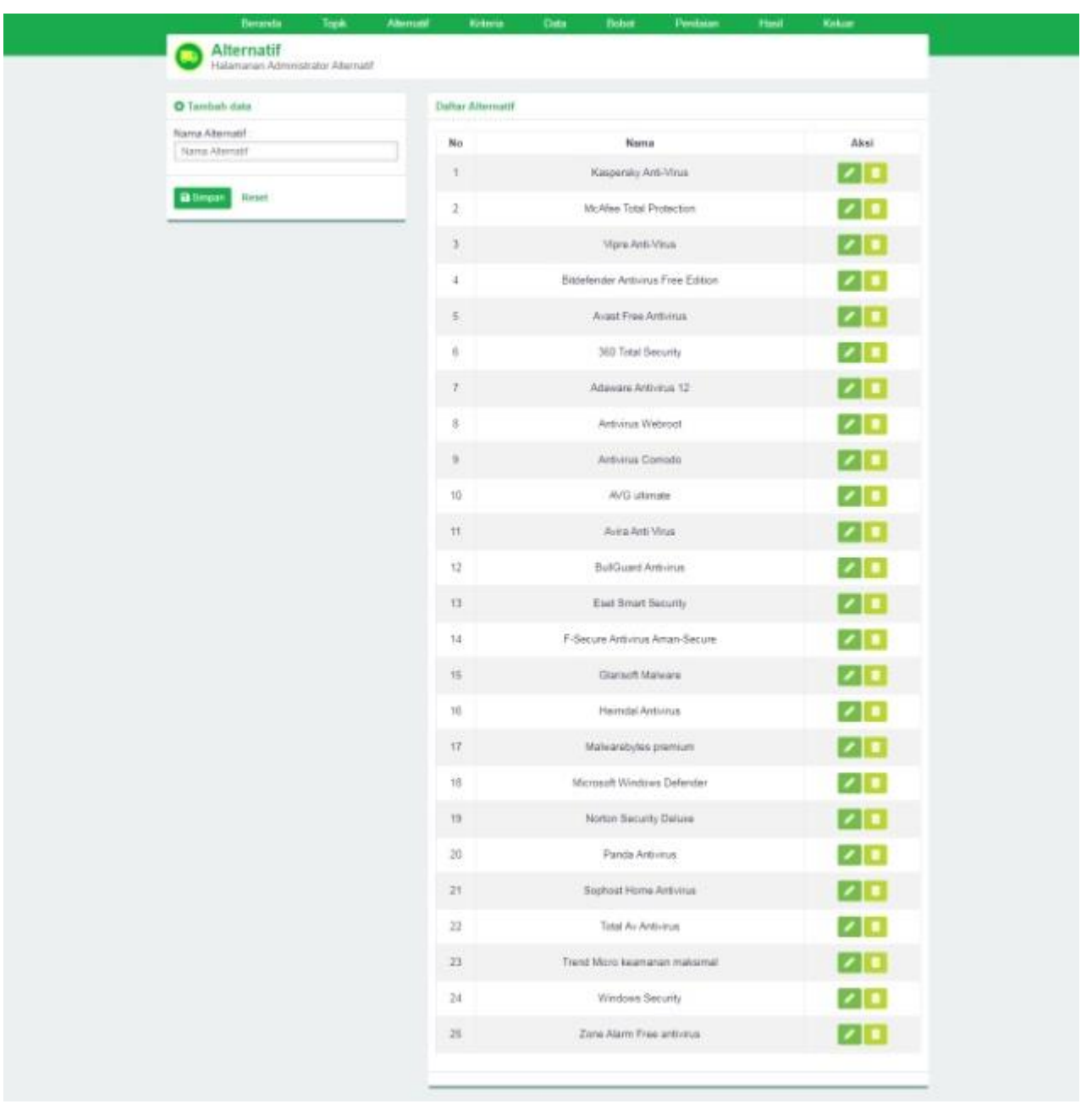

Fig. 6 Add Alternative Data

\section{Web Application Calculation Results}

At this stage of the calculation process happens and get started on ranking results from the process $\mathrm{n}$ ormalisasi matrix and calculation of the preference value for all alternatives to get results on ranking. The results of the calculation of the alternative ranking process are shown in Figure 7 below. 
Journal of Computer Networks, Architecture and

High Performance Computing

Volume 3, Number 1, Januari 2021

Submitted : 12 February 2021

Accepted : 23 February 2021

https://doi.org/10.47709/cnapc.v3i1.936

Published : 2 March 2021

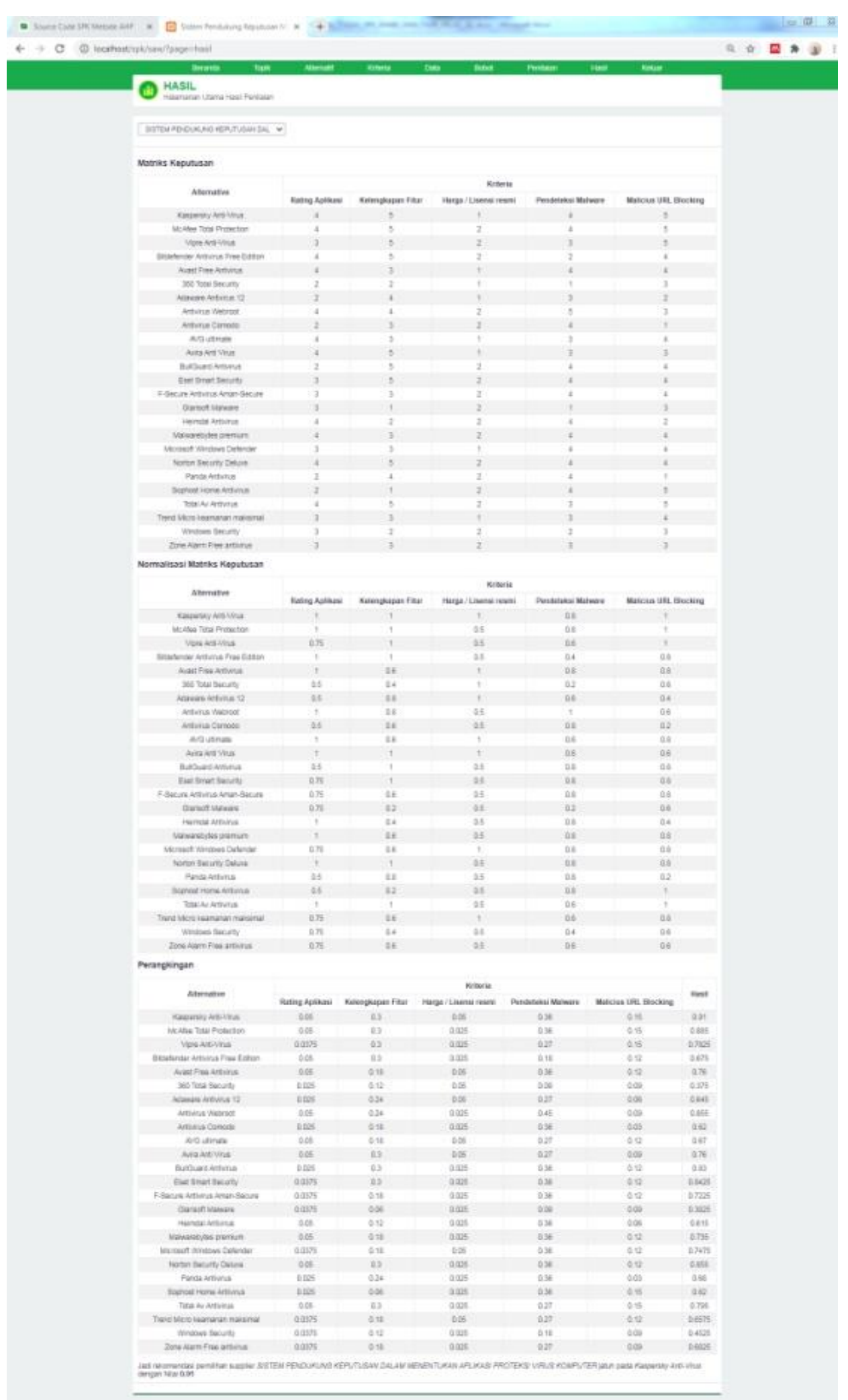

Fig. 7 Calculation Results of All Alternatives Ranking Process. 


\section{Journal of Computer Networks, Architecture and High Performance Computing}

Volume 3, Number 1, Januari 2021

https://doi.org/10.47709/cnapc.v3i1.936
Submitted : 12 February 2021

Accepted : 23 February 2021

Published : 2 March 2021

\section{DISCUSSIONS}

From this research, it is known that the use of the Simple Additive Weighting (SAW) method in determining the computer virus protection application. Then the method is made into a web-based application with the data entered is the criteria, criterion weights, attributes, variable values and alternative computer virus protection applications. There are 5 criteria for the process of determining computer virus applications using the Simple Additive Weighting (SAW) method, namely $\mathrm{K} 1$ = Application Rating, $\mathrm{K} 2=$ Completeness of Features, $\mathrm{K} 3$ = Price $/$ Official License, $\mathrm{K} 5=$ Malware Detection, K5 = Malicious Url Blocking with the weight of each criterion namely $\mathrm{K} 1=5 \%, \mathrm{~K} 2=30 \%, \mathrm{~K} 3$ $=5 \%, \mathrm{~K} 4=45 \%, \mathrm{~K} 5=15 \%$. And there are also 25 alternative protection applications that are inputted into the web application so that the results of computer virus protection application rankings are obtained.

\section{CONCLUSION}

The conclusion in this study is the ranking results of computer virus protection applications using the Simple Additive Weighting (SAW) method which is made through a web-based application and there are 25 alternative applications that were carried out in this study. After the ranking process was carried out, the results obtained were in accordance with the highest ranking of the virus protection application, Kaspersky anti-viruss. The Kaspersky antivirus application has variable values for each criterion, namely $\mathrm{K} 1=4, \mathrm{~K} 2=5, \mathrm{~K} 3=1, \mathrm{~K} 4=4, \mathrm{~K} 5=5$. This application is an inexpensive and free application and its complete features are not inferior to paid computer virus protection applications. It is hoped that this research can provide learning information to readers to find the best anti-virus application recommendations.

\section{REFERENCES}

Devi, K. D., \& Kumar, K. M. (2016). An Analysis of Various Anti-Virus Software Tools Based On Different Effective Parameters. International Journal of Computer Science Trends and Technology (IJCST), 4(4), 104-110.

Handika Siregar, Y., Dedi Irawan, M., \& Hazarin Aulia Chaniago, A. (2020). Penerapan Metode Analytical Hierarchy Process (AHP) dalam Perekrutan Petugas Keamanan. Jurnal Informatika Universitas Pamulang, 5(3), 371-378.

Haswan, F. (2019). Application of Simple Additive Weighting Method to Determine Outstanding School Principals. SinkrOn, 3(2), 186. https://doi.org/10.33395/sinkron.v3i2.10082

Hermawan, R. (2016). Analisa Cara Kerja dan Dampak dari Serangan Virus Spyware. Jurnal String, 1(1), 10-18.

Kaliszewski, I., \& Podkopaev, D. (2016). Simple additive weighting-A metamodel for multiple criteria decision analysis methods. Expert System With Applications, 54, 155-161.

Limbong, T., \& dkk. (2020). Sistem Pendukung Keputusan: Metode dan Implementasinya (A. Rikki, ed.). Medan: Yayasan Kita Menulis.

Niroomand, S., Mosallaeipour, S., \& Mahmoodirad, A. (2020). A Hybrid Simple Additive Weighting Approach for Constrained Multicriteria Facilities Location Problem of Glass Production Industries Under Uncertainty. IEEE Transactions on Engineering Management, 67(3), 846-854.

Nurhayati, A., Gautama, A., \& Naseer, M. (2018). Decision making model design for antivirus software selection using Factor Analysis and Analytical Hierarchy Process. MATEC Web of Conferences, 154, 1-6. https://doi.org/10.1051/matecconf/201815403006

Nurmalini, N., \& Rahim, R. (2017). Study Approach of Simple Additive Weighting For Decision Support System. International Journal of Scientific Research in Science and Technology, 3(3), 541-544. https://doi.org/10.31227/osf.io/8sjvt

Primandari, L. A. (2016). Penentuan Prioritas Mahasiswa dalam Memilih Antivirus dengan Menggunakan Analytic Hierarchy Process (AHP) (Studi Kasus di STMIK PPKIA Pradnya Paramita Malang). SMATIKA Jurnal, 6(1), $42-50$.

Saputri, S. W. (2018). Pemilihan Software Antivirus Untuk Laboratorium Komputer Akuntansi Dengan Metode Ahp ( Analytical Hierarchy Process ). Jurnal Akuntansi: Kajian Ilmiah Akuntansi (JAK), 5(2), 159. https://doi.org/10.30656/jak.v5i2.672

Sari, F. (2018). Metode Dalam Pengambilan Keputusan. Yogyakarta: Deepublish.

Senthil Kumar, K., \& Malathi, D. (2018). Context free grammar identification from positive samples. International Journal of Engineering and Technology(UAE), 7(3.12 Special Issue 12), 1096-1097. https://doi.org/10.14419/ijet.v7i3.11983

Tanjung, D. Y. H., \& Adawiyah, R. (2019). Optimizing Selection of Decision Support System with Fuzzy Simple 
Journal of Computer Networks, Architecture and

\section{High Performance Computing}

Volume 3, Number 1, Januari 2021

https://doi.org/10.47709/cnapc.v3i1.936

Submitted : 12 February 2021

Accepted : 23 February 2021

Published : 2 March 2021

Additive Weighting. International Conference on Cyber and IT Service Management, CITSM, (Citsm), 1-4. https://doi.org/10.1109/CITSM.2018.8674360

Widarma, A., Siregar, Y. H., Irawan, M. D., \& Fadhillah, S. (2020). Sistem Pendukung Keputusan Menentukan Tempat KKN (Kuliah Kerja Nyata) Menggunakan Metode Logika Fuzzy. CESS (Journal of Computer Engineering, System and Science), 5(2), 299. https://doi.org/10.24114/cess.v5i2.19665 